\title{
STRATEGI KEMENTERIAN AGAMA DALAM MENINGKATKAN MUTU MANAJEMEN MADRASAH ALIYAH DI KABUPATEN SELUMA
}

\author{
Suhirman $^{1}$ \\ Dosen Institut Agama Islam Negeri (IAIN) Bengkulu \\ Email: suhirman@iainbengkulu.ac.id \\ Idi Syatriawan ${ }^{2}$ \\ Email: edisyatriawan@gmail.com
}

\begin{abstract}
The purpose of the research is to describe the strategy of the Ministry of Religious Affairs in Improving the Quality of Madrasah Aliyah Management in Seluma District. This type of research includes qualitative research. The subject of this study was head of Seluma, Head of Madrasah and principal. Instrument of data collection using observation, interview and documentation, Technique of data analysis with qualitative data analysis done interactively and progress continuously until complete, so that data is saturated. The results of this study indicate that the strategy of the Ministry of Religious Affairs in improving the quality of Madrasah Aliyah management in Seluma Regency by improving the academic and non academic quality by meeting the 8 national education standards in accordance with the PP. 32 Year 2013 which includes content standards, process standards, equipment and infrastructure standards, graduation competency standards, management competency standards, financing competency standards, competency standards of educators and education personnel as well as assessment competency standards. Constraints experienced by the Ministry of Religious Affairs Seluma in improving the quality of Madrasah Aliyah management such as teachers and educators who have not met the academic standards, still low ability to take advantage of IT, and Infrastructure Inadequate. The solution to overcome obstacles in improving the quality of Madrasah Aliyah management by the Seluma Regency ministry is to motivate teachers to improve their educational qualifications, to include teachers in workshops and training, to activate KKG activities and to use IT such as internet, communication tools and social media Others.
\end{abstract}

Keywords: Strategy, Ministry of Religious Affairs, Quality of Madrasah Aliyah Management.

Abstrak: Tujuan penelitian adalah untuk mendiskripsikan strategi Kementerian Agama Dalam Meningkatkan Mutu Manajemen Madrasah Aliyah di Kabupaten Seluma. Jenis penelitian ini termasuk penelitian kualitatif. Subjek penelitian ini kepala kemenag Seluma, Kasi madrasah dan kepala sekolah. Instrumen pengumpulan data menggunakan observasi, wawancara dan dokumentasi, Teknik analisa data dengan analisis data kualitatif dilakukan secara interaktif dan berlangsung secara terus menerus sampai tuntas, sehingga datanya sudah jenuh. Hasil penelitian ini menunjukan bahwa strategi kementrian agama dalam peningkatan mutu manajemen Madrasah Aliyah di Kabupaten Seluma dengan cara meningkatkan mutu akademik dan non akademik dengan memenuhi 8 standar pendidikan nasional sesuai dengan PP No. 32 Tahun 2013 yang meliputi standar isi, standar proses, standar sarana dan prasarana, standar kompetensi kelulusan, standar kompetensi pengelolaan, standar kompetensi pembiayaan, standar kompetensi pendidik dan tenaga kependidikan serta standar kompetensi penilaian. Kendala yang dialami oleh kementerian agama Kabupaten Seluma dalam meningkatkan mutu manajemen Madrasah Aliyah seperti guru dan tenaga pendidik yang belum memenuhi standar akademik, masih rendahnya kemampuan memanfaatkan IT, dan Sarana Prasarana kurang memadai. Solusi mengatasi mengatasi kendala dalam peningkatan mutu manajemen Madrasah Aliyah yang dilakukan oleh kementerian agama Kabupaten Seluma adalah memotivasi guru agar meningkatkan kualifikasi pendidikan, mengikut sertakan guru dalam workshop dan pelatihan, mengaktifkan kegiatan KKG, dan harus bisa menggunakan IT seperti internet, alat komunikasi dan social media lainnya.

Kata kunci: Strategi, Kementerian Agama, Mutu Manajemen Madrasah Aliyah.

\section{Pendahuluan}

Berbicara mengenai kualitas sumber daya manusia, Islam memandang bahwa pembinaan sumberdaya manusia tidak dapat dilepaskan dari pemikiran mengenai manusia itu sendiri, dengan demikian Islam memiliki konsep yang sangat jelas, utuh dan komprehensif mengenai pembinaan sumberdaya manusia yang berkualitas. Konsep ini tetap aktual dan relevan untuk diaplikasikan sepanjang zaman. ${ }^{3}$

\footnotetext{
Penulis 1 Dosen IAIN Bengkulu

${ }^{2}$ Penulis 2 Mahasiswa Program Studi Manajemen Pendidikan Islam Pascasarjana IAIN Bengkulu

${ }^{3}$ Abudin Nata, Manajemen Pendidikan: Mengatasi Kelemahan Pendidikan Islam di Indonesia, Edisi Kedua, cet. Ke-3 (Jakarta: Kencana Predia Media Group, 2008), h. 17
} 
Fakta historis menyatakan bahwa pendidikan memegang peranan penting dalam upaya meningkatkan harkat dan martabat manusia dalam kehidupan guna memperoleh status yang mereka dambakan, lebih-lebih diakui bahwa melalui pendidikanlah akan terlahir generasi yang beramal dan berilmu. Belakangan ini asumsi sebagian masyarakat terhadap lembaga pendidikan terkesan kurang baik. Hal ini menjadi wajar adanya, disebabkan oleh maraknya tindakan asusila dan tindakan negatif lainnya yang dilakukan oleh orang-orang yang inhern di lembaga pendidikan, baik itu dilakukan oleh siswa, mahasiswa, bahkan oleh pendidik dan tenaga kependidikan. Hal yang menjadi problem mendasar dan belum pernah final untuk dibincangkan dalam dunia pendidikan adalah mutu pendidikan. Ketidakpercayaan pengguna jasa institusi pendidikan terhadap mutu pendidikan ini disebabkan oleh pemahaman mengenai konsepkonsep manajemen mutu pendidikan masih kurang dipahami oleh sebagian dari stakeholder, untuk tidak mengatakan semuanya. Implikasinya adalah, seluruh tindakan dan kebijakan yang diterapkan menjadi aturan-aturan yang tanpa dasar. ${ }^{4}$

Pada saat ini Kementerian Agama Kabupaten Seluma berkomitmen untuk meningkatkan mutu pendidikan yang diselenggarakan oleh madrasah baik negeri maupun swasta, madrasah diminta untuk meningkatkan kualitas mutu pendidikan, agar madrasah menjadi nomor satu pilihan masyarakat untuk pendidikan putra-putrinya. Mutu pendidikan merupakan syarat utama madrasah dalam keberhasilan penyelenggaraan pendidikan nasional seperti yang diharapkan oleh pemerintah. Selama ini hanya sebagian madrasah yang dianggap mempunyai mutu yang baik oleh masyarakat. Sementara masih banyak madrasah, terutama swasta dan terletak di desa yang merasa kesulitan untuk mengembangkan pendidikan di tengah persaingan dengan lembaga pendidikan formal lainnya.

Seluruh aspek terkait penyelenggaraan pendidikan di madrasah akan dinilai. Setelah dinilai akan dilakukan evaluasi serta dianalisa faktor penyebab seperti peran Kementerian Agama terhadap peningkatan mutu pendidikan madrasah baik negeri maupun swasta belum maksimal, madrasah diminta untuk meningkatkan kualitas mutu pendidikan akan tetapi bantuan dana masih kurang, pembinaan terhadap peningkatkan kedisiplinan guru, baik dari segi

${ }^{4}$ Abudin Nata, Manajemen Pendidikan: Mengatasi Kelemahan Pendidikan ...h. 19 administrasi pembelajaran maupun disiplin waktu mengajar masih kurang, Jumlah guru yang berstatus PNS masih kurang dan masih didominasi guru honorer. Setelah itu akan dicarikan bersama-sama solusi untuk mengatasi masalah yang dialami oleh madrasah, jika madrasah itu mempunyai hambatan dalam penyelenggaraan pendidikan. Pada saat ini kenyataannya pada madrasah masih kekurangan guru PNS (Pegawai Negeri Sipil), kompetensi guru yang tidak sesuai dengan disiplin keilmuan, kurangnya sarana dan prasarana madrasah dan kurangnya dana yang terserap untuk membangun dalam peningkatkan mutu madrasah. Hal ini dapat menyebabkan kuantitas dan kualitas yang berdampak kepada peserta didik dan menurunnya minat untuk menempuh pendidikan pada madrasah ${ }^{5}$

Berdasarkan pemikiran di atas maka penulis ingin mengangkat penelitian ini dengan judul "Strategi Kementerian Agama dalam meningkatkan mutu manajemen madrasah aliyah di Kabupaten Seluma”.

\section{Rumusan Masalah}

Berdasarkan batasan masalah di atas, maka disusun rumusan masalah sebagai berikut:

1. Bagaimana strategi Kementerian Agama dalam meningkatkan mutu manajemen madrasah Aliyah di Kabupaten Seluma ?

2. Apa saja yang menjadi kendala dalam pelaksanaan strategi Kementerian Agama dalam meningkatkan mutu manajemen madrasah Aliyah?

3. Bagaimana solusi dalam pelaksanaan strategi Kementerian Agama dalam meningkatkan mutu manajemen madrasah Aliyah?

\section{Tujuan Penelitian}

Merujuk pada perumusan masalah di atas, tujuan dari penelitian ini adalah untuk menganalisis beberapa hal sebagai berikut, yaitu:

1. Untuk mendiskripsikan strategi Kementerian Agama dalam meningkatkan mutu manajemen madrasah Aliyah di Kabupaten Seluma ?

2. Untuk mendiskripsikan kendala dalam pelaksanaan strategi Kementerian Agama dalam meningkatkan mutu manajemen madrasah Aliyah?

3. Untuk mendiskripsikan solusi dalam pelaksanaan strategi Kementerian Agama dalam meningkatkan mutu manajemen madrasah Aliyah?.

\footnotetext{
${ }^{5}$ Berdasarkan hasil pengamatan sementara penulis di Kementerian Agama Kabupaten Seluma. pada tanggal 2 Februari 2017.
} 


\section{Kegunaan Penelitian}

1. Secara teoritis dapat memberikan sumbangan pemikiran dalam strategi kementerian agama Kabupaten Seluma dalam meningkatkan mutu madrasah Aliyah.

2. Secara praktis untuk dapat dijadikan sumber penelitian selanjutnya.

\section{Metode Penelitian}

Jenis penelitian ini termasuk penelitian kualitatif. Penelitian ini berusaha mendeskripsikan tentang strategi Kemenag Kabupaten Seluma dalam Meningkatkan mutu pendidikan madrasah. Jenis penelitian ini termasuk penelitian kualitatif yang menyajikan secara langsung hakikat hubungan antara peneliti dan responden yang bukan berupa data angka melainkan kata-kata dan prilaku orang. Penelitian kualitatif membuka lebih besar terjadinya hubungan langsung langsung antara peneliti dan responden. ${ }^{6}$

\section{Kajian Teori \\ a. Strategi}

Strategi adalah sebagai cara untuk mencapai sebuah hasil akhir, menggambarkan strategi sebagai arah yang dipilih organisasi untuk diikuti dalam mencapai misinya. ${ }^{7}$ Mintzberg menawarkan lima kegunaan dari kata strategi sebagaimana yang dikutip Oliver yaitu a) Sebuah rencana, suatu arah tindakan yang diinginkan secara sadar, b) Sebuah cara, suatu maneuver spesifik yang dimaksudkan untuk mengecoh lawan atau komputitor, c) Sebuah pola, dalam suatu rangkaian tindakan, d) Sebuah posisi, suatu cara menempatkan organisasi dalam sebuah lingkungan, e) Sebuah prspeksif, suatu cara yang terintegrasi dalam memandang dunia. ${ }^{8}$

\section{b. Upaya Kementerian Agama meningkatkan mutu madrasah}

Adapun upaya Kementerian Agama meningkatkan mutu madrasah melalui beberapa program melalui program strategis seperti:

1). Keberpihakan kepada rakyat kecil atau ekonomi kurang mampu.

Setiap program pendidikan harus berpihak kepada seluruh masyarakat terutama masyarakat yang kurang

${ }^{5}$ Berdasarkan hasil pengamatan sementara penulis di Kementerian Agama Kabupaten Seluma. pada tanggal 2 Februari 2017.

${ }^{6}$ Molleong J. Lexy, Penelitian Kualittaif, (Bandung, Remajarosdakarya, 1995) h. 5

${ }^{7}$ Sandra Oliver, Strategi Public Relations, PT. Gelora Aksara Pramata, London: 2006.h.2

${ }^{8}$ Sandra Oliver, Strategi Public Relations,... h.2 mampu. Progran ini dimaksudkan agar orang-orang yang krang mampu dibidang ekonomi dapat mengeyam atau memperoleh pendidikan yang bermutu sebagaimana halnya yang diperoleh orang-orang yang mampu. Selama ini hanya orang-orang mampu dibidang dibidang ekonomi yang dapat menikmati pendidikan yang bermutu karena biaya pendidikan cukup mahal. Berkenaan hal tersbut, dengan telah digulirkan Bantuan Oprasional Sekolah (BOS) untuk pendidikan dasar maka setiap warga Negara Indonesia pada usia sekolah baik yang berada di perktaan maupun di daerah terpencil harus dapat menyelesaikan pendidikan dasar 9 tahun atau setingkat Sekolah Tingkat Lanjutan Pertama. ${ }^{9}$

2). Pemberdayaan pelaku utama pendidikan.

Setiap anggaran pendidikan yang dikelurkan harus diarahkan dan diutamakan untuk pelaku utama pendidikan. Maksudnya adalah bahwa setiap dana yang dikeluarkan untuk peningkatan mutu pendidikan hendaknya sampai kepada sasaran yakni: siswa yang belajar dan guru yang mengajar serta kegiatan proses belajar mengajar bukan pada berokrasi pendidikan yang hanya merupakan figuran. Dengan demikian, untuk birokrasi dalam pelaksanaan pendidikan hanya sebagai koordinator dan pemantau serta evaluator dalam pelaksanaan.

3). Pemberian Bantuan atau Subsidi,

Bantuan atau subsidi yang berjumlah kecil berskala nasional ditiadakan lalu diganti dengan program bantuan yang jumlahnya besar meskipun hanya baru beberapa madrasah yang mendapatkanya. Dengan demikian diharapkan ada perubahan yang signifikan pada madrasah yang mendapatkan bantuan. Dengan cara ini pula diharapkan dapat memacu madrasah untuk membuat program dan melaksanakan kegiatan yang mengacu pada peningkatan mutu hasil lulusan suatu madrasah. Setelah suatu madrasah tertentu telah maju dengan segala fasilitas dan sarana pendidikannya maka bantuan akan diarahkan kepada madrasah yang lain. ${ }^{10}$

4). Mengejar ketertinggalan.

Program ini dimaksudkan untuk memacu seluruh madrasah di Indonesia agar melakukan suatu upaya agar mampu mengajar ketinggalan dengan sekolah yang dibawah naungan Kementerian Pendidikan Nasional. Dengan upaya ini madrasah tidak lagi dipandang sebelah mata atau dianggap sekolah ke,las dua. Kedepan para orang tua siswa diharapkan dengan bangga menyekolahkan anaknya pada madrasah. ${ }^{11}$

\footnotetext{
${ }^{9}$ Abdul Manab. Manajemen Kurikulum Pembeajaran di Madrasah.... h. 110

${ }^{10}$ Abdul Manab. Manajemen Kurikulum Pembelajaran di Madrasah.... h.112 h. 113
} 
c. Konsep Madrasah

Madrasah adalah sekolah umum yang bercirikan Islam. ${ }^{12}$ Pengertian ini menunjukan bahwa dari segi materi kurikulum madrasah mengajarkan pengetahuan umum yang sama dengan sekolah-sekolah umum sederajat. Kata Madrasah merupakan isim makan dari kata darasa yang berarti belajar. Dengan demikian Madrasah mempunyai pengertian tempat belajar, karenanya istilah madrasah tidak hanya diartikan sekolah dalam arti sempit, tetapi bisa dimaknai rumah, istana, kuttab, perpustakaan, surau, masjid dan lain-lain. ${ }^{13}$

Dalam sejarah pendidikan Islam, makna dari madrasah tersebut memegang peran yang sangat penting sebagai institusi belajar umat Islam selama pertumbuhan dan perkembangannya. Madrasah adalah jenis lembaga pendidikan yang pendirian dan penyelenggaraannya didorong oleh hasrat dan semangat cita-cita untuk mengejawantahkan nilainilai Islam, baik yang tercermin dari nama lembaganya maupun dalam kegiatan-kegiatan yang diselenggarakannya.

Menurut SKB 3 menteri Tahun 1975, yang dimaksud dengan Madrasah ialah lembaga pendidikan yang menjadikan mata pelajaran agama Islam sebagai mata pelajaran dasar, yang diberikan sekurang-kurangnya $30 \%$ disamping mata pelajaran umum.

Kurikulum pendidikan di Madrasah disamping memakai Kurikulum Departemen Agama juga memakai kurikulum Departemen Pendidikan Nasional ditambah dengan kurikulum muatan lokal yang bernuansa keagamaan, sehingga diharapkan nanti siswa dapat menyelesaikan semua persoalan agama terutama yang ada kaitannya dengan kehidupan social kemasyarakatan.

d. Peningkatan Mutu Manajemen Madrasah.

1. Pengertian Mutu

Mutu adalah faktor keputusan mendasar dari pelanggan mutu. Mutu adalah penentuan pelanggan, bukan ketetapan pengguna manajemen. Menurut Edward Sallis, mutu dapat didefinisikan sebagai sesuatu yang memuaskan dan melampaui kebutuhan pelanggan. Definisi ini disebut dengan istilah, mutu sesuai persepsi (Quality in perception). ${ }^{14}$ Mutu merupakan sebuah filosofi dan metodologi yang membantu institusi untuk merencanakan perubahan

${ }^{12} 12$ Zulkarnain, Transformasi nilai-nilai pendidikan Isla . Jakarta. Pustaka Pelajar. 2008.h.30.

${ }^{13}$ Habib Husnial Pardi. Sejarah Sosial Pendidikan Islam ,Kencana Jakarta,2005.h. 214.

${ }^{14}$ Edward Sallis, Total Quality Manajemen. In Education. Manajemen Mutu Pendidikan. Yogyakarta.IRCisod. 2008, h. 56 dan mengatur agenda dalam menghadapi tekanantekanan eksternal berlebihan. Peningkatan mutu menjadi semakin penting bagi institusi yang digunakan untuk memperoleh kontrol yang lebih baik melalui usahanya sendiri. Gerakan mutu terpadu dalam pendidikan masih tergolong baru. Ada banyak gagasan yang dihubungkan dengan mutu juga dikembangkan dengan baik oleh institusi-institusi pendidikan tinggi dan gagasan mutu tersebut terus menerus diteliti dan diimplementasikan di sekolahsekolah.

Penjelasan mengenai mutu yang lain disampaikan dalam buku Manajemen Pendidikan oleh Tim Dosen Administrasi Pendidikan Universitas Pendidikan Indonesia, mutu memiliki variasi sebagaimana didefinisikan oleh masing-masing orang atau pihak. Produsen (penyedia barang/jasa) atau konsumen (pengguna/pemakai barang/jasa) akan memiliki definisi yang berbeda mengenai mutu barang/jasa. Perbedaan ini mengacu pada orientasi masing-masing pihak mengenai barang/jasa yang menjadi obyeknya. Satu kata yang menjadi benang merah dalam konsep mutu baik menurut konsumen maupun produsen adalah kepuasan. Barang atau jasa yang dikatakan bermutu adalah yang dapat memberikan kepuasan baik bagi pelanggan maupun produsennya. ${ }^{15}$

\section{Pembahasan}

\section{Strategi Peningkatan Mutu Manajemen Ma- drasah Aliyah}

Berdasarkan hasil penelitian di atas penulis akan membahas tentang strategi kementrian agama dalam peningkatan mutu manajemen Madrasah Aliyah di Kabupaten Seluma dari beberapa aspek yang diuraikan sebagai berikut:

1) Standar Isi

Salah satu cara yang ditempuh untuk meningkatkan mutu Madrasah Aliyah adalah dengan selalu memperbaharui kurikulum sesuai dengan yang berlaku. Agar proses belajar di Madrasah Aliyah dapat sesuai dengan ruang lingkup materi dan tingkat kompetensi yang dituangkan dalam kriteria tentang kompetensi tamatan, kompetensi bahan kajian, kompetensi mata pelajaran, dan silabus pembelajaran yang harus dipenuhi oleh peserta didik pada jenjang dan jenis pendidikan Madrasah Aliyah.

Berdasarkan data penelitian dari 2 Madrasah Aliyah di wilayah kabupaten Seluma, satu Madra-

${ }^{15}$ Tim Dosen Administrasi Pendidikan Universitas Pendidikan Indonesia. Manajemen Pendidikan (Bandung : Alfabeta, 2011), h. 293. 
Suhirman | Strategi Kementerian Agama Dalam Meningkatkan Mutu

sah Aliyah Swasta masih menggunakan kurikulum KTSP dan baru 1 Madrasah Aliyah Negeri yang sudah menerapkan kurikulum 2013 dalam pembelajarannya.

2) Standar Proses

Peningkatan mutu belajar di dalam Madrasah dapat ditempuh dengan cara meningkatkan mutu guru sebagai pengajar di dalam Madrasah, peningkatan model dan media belajar di dalam Madrasah, serta peningkatan kualitas belajar di dalam Madrasah Aliyah. Kegiatan monitoring dan evaluasi dilakukan dalam rangka pengawasan dan pengendalian kegiatan yang sedang dilaksanakan, untuk umpan balik pelaksanaan kegiatan yang sedang berjalan. Monitoring dan evaluasi dilakukan dengan melihat langsung pelaksanaan kegiatan, untuk mengetahui kesesuaian antara perencanaan dan pelaksanaan dengan keberhasilan program.

Strategi Kementerian Agama dalam mengembangkan Madrasah dapat dilakukan melalui langkah-langkah sebagai berikut : (1) Peningkatan mutu jenjang pendidikan pada perguruan agama islam sesuai dengan perkembangan ilmu dan teknologi. (2) Pembinaan Madrasah negeri diusahakan menjadi contoh bagi Madrasah swasta terutama dalam soal mutu. (3) Pembinaan Madrasah swasta diusahakan agar system pendidikannya selaras dengan system pendidikan nasional. ${ }^{16}$

Selain itu ketua kelompok kerja pengawas (POKJAWIS) kabupaten Seluma dalam pemaparannya menambahkan bahwa strategi lain yang dilakukan oleh kementrian agama Kabupaten Seluma adalah dengan "melakukan peningkatan standar pelayanan minimal (SPM) untuk menuju standar nasional (SNP) yang menjadi tanggung jawab pemerintah."

Standar pelayanan minimal bidang pendidikan yang selanjutnya disebut SPM adalah jenis dan tingkat pelayanan pendidikan minimal yang harus disediakan oleh satuan atau program pendidikan, penyelenggara satuan atau program pendidikan, pemerintah provinsi, dan pemerintah kabupaten/ kota sebagaimana diatur dalam Peraturan Pemerintah Nomor 38 Tahun 2007 tentang Pembagian Urusan Pemerintahan Antara Pemerintah Pusat, Pemerintahan Daerah Provinsi, dan Pemerintahan Daerah Kabupaten/Kota. ${ }^{17}$

Standar nasional pendidikan (SNP) adalah sebagaimana diatur dalam Peraturan Pemerintah Nomor 32 Tahun 2013 tentang Standar Nasional Pendidikan dan peraturan perundangan lain yang relevan. Menurut Peraturan Mentri Pendidikan Nasional No 63 Tahun 2009 Tentang Sistem Penjamin

${ }^{16} \mathrm{http}: / /$ pendis.kemenag.go.id/index.php?a=artikel\&id2=sejarahpend is\#.WFiTA9J97IU

${ }^{17} \mathrm{http}: / /$ deuniv.blogspot.co.id/2015/03/pengenalan-snp-spm-danspmp-dalam.html
Mutu Pendidikan pasal 13 ayat (1) SNP bagi satuan atau program pendidikan nonformal dirumuskan sedemikian rupa sehingga tidak menghilangkan atau mengurangi keluwesan dan kelenturan pendidikan nonformal dalam melayani pembelajaran peserta didik sesuai dengan kebutuhan, kondisi, dan problematika yang dihadapi masing-masing peserta didik.

Mutu pendidikan adalah tingkat kecerdasan kehidupan bangsa yang dapat diraih dari penerapan Sistem Pendidikan Nasional. Tugas kementrian agama mendorong, menstimulasi, dan memfasilitasi umat agar tergerak hatinya ikut memikirkan pengembangan Madrasah. Mengaktualkan potensi umat islam dan para pengelolanya harus didorong agar mampu berkreasi secara mandiri dengan melakukan terobosan baru.

Kegiatan-kegiatan yang sudah dilakukan oleh kementrian agama dalam tugasnya mengembangkan Madrasah Aliyah seperti "mengadakan bintek, workshop, pembinaan dan sosialisasi dan mengadakan kontrol dan pengawasan secara intensif" Bimbingan Teknis (Bintek) adalah suatu kegiatan yang dimaksudkan untuk memberikan bantuan yang biasanya berupa tuntunan dan nasehat untuk menyelesaikan persoalan/masalah yang bersifat teknis. Tujuan pelaksanaan Bintek untuk menyelesaikan masalah/kasus yang terjadi dan dihadapi oleh para pejabat sehingga penyelesaiannya dapat dipertanggungjawabkan sesuai dengan peraturan perundang-undangan yang berlaku. Bintek dilaksanakan oleh Satker terkait, dengan metode tatap muka/ ceramah.

Workshop atau training jika diartikan dalam bahasa indonesia artinya pelatihan. Dengan definisi seperti itu sudah sangat jelas bahwa kita benarbenar akan praktek. Workshop atau training bersifat "learning by doing", dipandu oleh si pelatih dan praktik apa yang diajarkan. Workshop guru dimasksud disini adalah pelatihan bagi guru madrasah Aliyah untuk dapat meningkatkan kompetensinya.

Proses sosialisasi dilakukan dengan membimbing individu ke dalam dunia sosial. Sosialisasi ialah hubungan interaktif yang dengannya seseorang mempelajari keperluan-keperluan sosial dan kultural yang menjadikan seseorang sebagai anggota masyarakat. Posisi kepala Madrasah dan guru sebagai warga Madrasah harus dapat menyampaikan kepentingan pendidikan kepada warga Madrasah tidak terkecuali wali murid.

3) Standar Sarana dan Prasarana

Standar sarana dan prasarana merupakan standar nasional pendidikan yang berkaitan dengan kriteria minimal tentang ruang belajar, tempat berolahraga, tempat beribadah, perpustakaan, laboratorium, bengkel kerja, tempat bermain, tempat 
berkreasi dan berekreasi, serta sumber belajar lain, yang diperlukan untuk menunjang proses pembelajaran, termasuk penggunaan teknologi informasi dan komunikasi.

4) Standar Kompetensi Kelulusan

Beberapa hal yang dapat dilakukan untuk meningkatkan mutu Madrasah Aliyah adalah dengan menigkatkan mutu belajar di dalam Madrasah Aliyah tersebut. Peningkatan mutu belajar di dalam Madrasah Aliyah dilaksanakan juga sebagai upaya peningkatan kelulusan siswa Madrasah Aliyah.

Model pembelajaran ialah pola yang digunakan sebagai pedoman dalam merencanakan pembelajaran di kelas maupun tutorial. Model pembelajaran di MA digunakan oleh guru dalam meyampaikan pembelajaran kepada siswa untuk memudahkan siswa memahami materi pelajaran dan dapat meningkatkan hasil evaluasi siswa. ${ }^{18}$

Sedangkan media pembelajaran menurut Gagne media adalah berbagai jenis komponen dalam lingkungan siswa yang dapat merangsangnya untuk belajar. Selain itu media adalah segala alat fisik yang dapat menyajikan pesan serta merangsang siswa untuk belajar. ${ }^{19}$

Model pembelajaran dan media pembelajaran yang digunakan di Madrasah Aliyah untuk tujuan yang sama yaitu meningkatkan kemampuan siswa dalam memahami materi yang diajarkan oleh guru di dalam kelas. Hal ini karena prestasi siswa pada sebuah Madrasah Aliyah akan menentukan mutu Madrasah tersebut. Maka sangat penting peran guru dalam menyampaikan materi yang mudah dipahami siswa dengan dibantu menggunakan model pembelajaran dan media pembelajaran. Menurut istilah, kata kualitas berarti mutu, yaitu tingkat baik buruknya sesuatu. Kualitas belajar MA salah satunya dapat dilihat dari baik buruknya prestasi siswa di dalam MA serta kinerja guru di dalam MA tersebut.

Faktor pendukung kualitas MA adalah kualitas belajar siswa yang baik di MA. Pendidikan atau Madrasah yang berkualitas disebut juga Madrasah yang berprestasi, Madrasah yang baik atau Madrasah yang sukses, Madrasah yang efektif dan Madrasah yang unggul. Madrasah yang unggul dan bermutu itu adalah Madrasah yang mampu bersaing dengan siswa di luar Madrasah. Juga memiliki akar budaya serta nilai-nilai etika moral (akhlak) yang baik dan kuat. ${ }^{20}$

${ }^{18}$ Agus Suprijono. Model-Model Pembelajaran. (Jakarta: Gramedia Pustaka Jaya, 2011), 46

${ }^{19}$ Arief S Sadiman, dkk. Media Pendidikan. (Jakarta: PT. Raja Grafindo Persada. 2007), 6

${ }^{20} \mathrm{Abdul}$ Chafidz, Sekolah Unggul Konsepsi dan Problematikanya, (MPA No. 142, Juli 1998), 39.
Selain itu, peningkatan kelulusan Madrasah Aliyah harus didukung dan disertai dengan pemenuhan sarana dan prasarana, peningkatan tenaga pendidik dan kependidikan melalui monitoring dan evaluasi. Strategi Kementerian Agama dalam mengembangkan Madrasah dilakukan melalui langkah-langkah sebagai berikut :

a. Peningkatan mutu jenjang pendidikan pada perguruan agama islam sesuai dengan perkembangan ilmu dan teknologi.

b. Pembinaan Madrasah negeri diusahakan menjadi contoh bagi Madrasah swasta terutama dalam soal mutu.

c. Pembinaan Madrasah swasta diusahakan agar system pendidikannya selaras dengan system pendidikan nasional.

5) Standar Kompetensi Pengelolaan

Tugas pokok dan fungsi seksi pendidikan Madrasah adalah Melaksanakan pelayanan, bimbingan, Pembinaan dan Pengelolaan sistem informasi dibidang pendidikan agama Islam :

a. penyiapan perumusan kebijakan teknis dan perencanaan di bidangpendidikan Madrasah;

b. pelaksanaan pelayanan, bimbingan dan pembinaan bidang kurikulum dan evaluasi, pendidik dan tenaga kependidikan, sarana prasarana, pengembangan potensi siswa, kelembagaan kerjasama, dan pengelolaan sistem informasi pendidikan madrasah.

c. evaluasi dan penyusunan laporan di bidang pendidikan Madrasah. ${ }^{21}$

Peraturan Pemerintah No 32 Tahun 2013 tentang Standar Nasional Pendidikan ditandaskan pada Pasal 55 ayat 1, Pengawasan satuan Pendidikan memiliki peran dan tugas untuk Pemantauan, supervisi, evaluasi, pelaporan dan tindak lanjut hasil pengawasan yang harus dilakukan secara teratur dan kesinambungan. Lebih lanjut pada Pasal 57 ditegaskan, bahwa tugas supervisi meliputi: Supervisi akademik dan manajerial terhadap keterlaksanaan dan ketercapaian tujuan pendidikan di Madrasah.

Pengawas Madrasah adalah guru pegawai negeri sipil yang diangkat dalam jabatan pengawas Madrasah (PP 74 tahun 2008). Pengawas adalah kegiatan pengawas Madrasah dalam menyusun program pengawasan, melaksanakan program pengawasan, evaluasi hasil pelaksanaan program, dan melaksanakan pembimbingan dan pelatihan profesional

${ }^{21}$ https ://sumsel.kemenag.go.id/artikel/39212/tugas-dan-fungsistruktur-kemenag-sumsel 
Suhirman | Strategi Kementerian Agama Dalam Meningkatkan Mutu 121

guru.

Pengawas Madrasah bertugas melakukan pengawasan terhadap dua hal penting dalam pendidikan di Madrasah, yaitu proses pendidikan dan pengelolaan Madrasah. Proses pendidikan terkait erat dengan kegiatan pengembangan potensi kognitif, afektif dan psikomotorik peserta didik. Sementara pengelolaan Madrasah berkaitan dengan pengaturan dalam memanfaatkan sumber daya Madrasah secara efektif dan efisien.

Guru di Madrasah merupakan orang yang memiliki kemampuan merancang program pembelajaran serta mampu menata dan mengelola kelas agar peserat didik dapat belajar dan pada akhirnya dapat mencapai tingkat kedewasaan sebagai tujuan akhir dari proses pendidikan. Untuk meningkatkan peran serta masyarakat dalam bidang pendidikan, diperlukan wadah yang dapat mengakomodasi pandangan, aspirasi, dan menggali potensi masyarakat untuk menjamin demokratisasi, transparansi, dan akuntabilitas. Salah satu wadah tersebut adalah Dewan Pendidikan di tingkat kabupaten/kota dan komite Madrasah di tingkat satuan pendidikan.

5) Standar Kompetensi Pembiayaan

Dana BOS terbukti memberikan dampak positif terhadap pendidikan di Madrasah Aliyah. (1) pihak sekolah sudah tidak memikirkan kekurangan biaya operasional sekolah lagi dan tentunya anak-anak Indonesia dapat mengakses sekolah. Depdiknas harus memaksa sekolah untuk meningkatkan kualitas dan layanan sekolah. (2) sejak diluncurkan program BOS terjadi peningkatan kualitas pendidikan sehingga sekolah yang kualitasnya masih rendah makin lama makin sedikit. (3) Program BOS juga meningkatkan penerimaan sekolah. Dengan dana BOS, sekolah dapat meningkatkan ketersediaan sarana dan prasarana belajar-mengajar, pendapatan guru (guru honor, guru kontrak, dan guru tetap), kegiatan ekstrakurikuler, pelajaran tambahan, dan mutu guru. Bahwa program BOS juga ditujukan untuk mencegah anak putus sekolah.

Terkait dengan perencanaan dan prosedur pengajuan dana bantuan operasional sekolah (BOS) pada Madrasah Aliyah di Kabupaten Seluma meliputi: perencanaan dana bantuan operasional sekolah disusun dalam bentuk rencana anggaran dan belanja sekolah. RAPBS disusun oleh tim penyusun RAPBS yang terdiri dari guru, dan komite sekolah yangmdibentuk oleh kepala sekolah. Menetapkan prioritas kegiatan yang akan dilaksanakan pada tahun pelajaran yang bersangkutan.

7) Standar Kompetensi Pendidik dan Tenaga Pendidik
Untuk menjadikan sebuah Madrasah Aliyah bermutu tentunya diperlukan peran serta dari guru sebagai tenaga pendidik. Seorang guru memegang peran penting dalam keberlangsungan sebuah Madrasah Aliyah. seperti diketahui guru merupakan pendidik professional yang tugas utamanya mendidik, mengajar, membimbing, mengarahkan dan melatih, menilai serta mengevaluasi peserta didik. Guru berinterkasi langsung dengan peserta didik dan dapat memberikan pengaruhi yang besar kepada peserta didik didalam Madrasah Aliyah. Maka kualitas guru akan sangat mempengaruhi kualitas mutu Madrasah.

Guru adalah orang dewasa yang secara sadar bertanggung jawab dalam mendidik, mengajar, dan membimbing peserta didik. ${ }^{22}$ Peran guru untuk meningkatkan mutu Madrasah Aliyah tempat dia mengajar sangatlah penting karena guru sebagai penggerak utama jalannya kegiatan di dalam Madrasah Aliyah tersebut. Kualitas dan kuantitas belajar siswa dalam kelas bergantung pada banyak faktor, antara lain ialah guru hubungan antara siswa di dalam kelas, serta kondisi umum suasana di dalam kelas. ${ }^{23}$

Kualitas guru Madrasah Aliyah di Kabupaten Seluma di tinjau dari kualifikasi ijazah menurut Bapak Jumaidi, dapat dibedakan menjadi 3 kelompok, yaitu: guru berijazah S1 sesuai dengan bidang ajarnya, guru berijazah S1 namun tidak sesuai dengan bidang ajarnya dan guru belum berijazah S1. Kuaifikasi guru dengan ijazah S1 menurut beliau adalah yang paling memungkinkan dapat memberikan bantuan besar dalam peningkatan mutu Madrasah Aliyah.

Standar Pendidik dan Tenaga Kependidik merupakan standar nasional tentang kriteria pendidikan prajabatan dan kelayakan fisik maupun mental serta pendidikan dalam jabatan dari tenaga guru dan tanaga kependidikan lainnya. Pendidik harus memiliki kualifikasi akademik dan kompetensi sebagai agen pembelajaran, sehat jasmani dan rohani, serta memiliki kemampuan untuk mewujudkan tujuan pendidikan nasional. Kualifikasi akademik sebagaimana dimaksud adalah tingkat pendidikan minimal yang harus dipenuhi oleh seorang pendidik yang dibuktikan dengan ijazah dan/atau sertifikat keahlian yang relevan sesuai ketentuan perundangundangan yang berlaku.

${ }^{22}$ Hamzah B. Uno. Teori motivasi dan pengukuran analisis di bidang pendidikan, (Jakarta: bumi aksara, 2008), 15.

${ }^{23}$ A.M. Sardiman. Interaksi dan Motivasi Belajar Mengajar. (Jakarta: Raja Grafindo Persada, 2001), 144 
Suhirman I Strategi Kementerian Agama Dalam Meningkatkan Mutu 122

Dapat kita lihat bahwa mutu Madrasah Aliyah di Kabupaten Seluma dipengaruhi oleh mutu guru, oleh karena itu untuk mendukung peningkatan mutu madrsah Aliyah (MA) perlu juga diperhatikan aspek guru atau tenaga pendidik yang tersedia di masing-masing Madrasah Aliyah.

Pembinaan, Workshop dan diklat, Supervise dan monitoring serta evaluasi dilakukan agar setiap usaha yang dilakukan untuk meingkatkan mutu Madrasah Aliyah dapat berjalan lancar. Tujuan diadakannya kegiatan diklat antara lain, adalah:

a. Mengubah paradigma/cara pandang, mind set, pola pikir, pola sikap, dan pola tindak untuk kaya mental, mencapai kinerja yang optimal dengan mengembangkan learning organization;

b. Menumbuhkembangkan nilai-nilai moral, meningkatkan kecerdasan spiritual, menggunakan seluruh tubuh, pikiran, hati dan jiwa untuk melaksanakan tugas, yang menyatu dengan kemampuan kepemimpinan, managerial, skill dan knowledge;

c. Mengubah cultural set untuk membangun sikap, perilaku, dan management beliefts dan values aparatur;

d. Membangun karakter dan jati diri;

e. Diklat berbasis kompetensi:

f. Memiliki kompetensi untuk secara optimal melaksanakan tugas jabatan yg diduduki;

g. Meningkatkan kompetensi untuk menduduki jabatan yang lebih tinggi;

h. Memiliki kompetensi menerapkan iptek baru untuk peningkatan kinerja organisasi;

i. Mengembangkan teknologi informasi (e-government) dan berbagai keterkaitannya (e-procurement, e-bidding, e-office)

Strategi yang dilakukan oleh kementrian agama dalam peningkatan mutu manajemen Madrasah Aliyah di kabupaten melalui beberapa kegiatan seperti, pembinaan, bintek, workshop dan diklat serta melakukan supervise dan monitoring, melakukan kegiatan evaluasi melalui kerjasama dengan forum kedinasan terkait.

Peningkatan mutu Madrasah Aliyah tidak bisa dilakukan hanya oleh kementrian agama saja tanpa bantuan dan peran aktif dari berbagai pihak terkait lainnya. Dalam rangka peningkatan mutu Madrasah Aliyah di Kabupaten Seluma salah satu forum kedinasan yang berperan seratd adalah KMMA kabupaten Seluma.

1. Standar Kompetensi Penilaian

Standar penilaian pendidikan adalah standar nasional pendidikan yang berkaitan dengan mekanisme, prosedur, dan instrumen penilaian hasil belajar peserta didik. Penilaian pendidikan adalah proses pengumpulan dan pengolahan informasi untuk menentukan pencapaian hasil belajar peserta didik. Penilaian dilakukan dengan menempuh beberapa cara, seperti:

a. Ulangan adalah proses yang dilakukan untuk mengukur pencapaian kompetensi peserta didik secara berkelanjutan dalam proses pembelajaran, untuk memantau kemajuan, melakukan perbaikan pembelajaran, dan menentukan keberhasilan belajar peserta didik.

b. Ulangan Harian adalah kegiatan yang dilakukan secara periodik untuk mengukur pencapaian kompetensi peserta didik setelah menyelesaikan satu Kompetensi Dasar (KD) atau lebih.

c. Ulangan Tengah Semester semester adalah kegiatan yang dilakukan oleh pendidik untuk mengukur pencapaian kompetensi peserta didik setelah melaksanakan 8 - 9 minggu kegiatan pembelajaran. Cakupan ulangan meliputi seluruh indikator yang merepresentasikan seluruh KD pada periode tersebut.

d. Ulangan akhir semester adalah kegiatan yang dilakukan oleh pendidik untuk mengukur pencapaian kompetensi peserta didik di akhir semester. Cakupan ulangan meliputi seluruh indikator yang merepresentasikan semua $\mathrm{KD}$ pada semester tersebut.

e. Ulangan kenaikan kelas adalah kegiatan yang dilakukan oleh pendidik di akhir semester genap untuk mengukur pencapaian kompetensi peserta didik di akhir semester genap pada satuan pendidikan yang menggunakan sistem paket. Cakupan ulangan meliputi seluruh indikator yang merepresentasikan $\mathrm{KD}$ pada semester tersebut.

f. Ujian sekolah/madrasah adalah kegiatan pengukuran pencapaian kompetensi peserta didik yang dilakukan oleh satuan pendidikan untuk memperoleh pengakuan atas prestasi belajar dan merupakan salah satu persyaratan kelulusan dari satuan pendidikan. Mata pelajaran yang diujikan adalah mata pelajaran kelompok mata pelajaran ilmu pengetahuan dan teknologi yang tidak diujikan dalam ujian nasional dan aspek kognitif dan/atau psikomotorik kelompok mata pelajaran agama dan akhlak mulia serta kelompok mata pelajaran kewarganegaraan dan kepribadian yang akan diatur dalam POS Ujian Sekolah/Madrasah.

g. Ujian Nasional yang selanjutnya disebut UN adalah kegiatan pengukuran pencapaian kom- 
Suhirman | Strategi Kementerian Agama Dalam Meningkatkan Mutu 123

petensi peserta didik pada beberapa mata pelajaran tertentu dalam kelompok mata pelajaran ilmu pengetahuan dan teknologi dalam rangka menilai pencapaian Standar Nasional Pendidikan.

h. Kriteria ketuntasan minimal (KKM) adalah kriteria ketuntasan belajar (KKB) yang ditentukan oleh satuan pendidikan. KKM pada akhir jenjang satuan pendidikan untuk kelompok mata pelajaran selain ilmu pengetahuan dan teknologi merupakan nilai batas ambang kompetensi. Penilaian hasil belajar peserta didik pada jenjang pendidikan dasar dan menengah didasarkan pada prinsip-prinsip sebagai berikut :

a. sahih, berarti penilaian didasarkan pada data yang mencerminkan kemampuan yang diukur.

b. objektif, berarti penilaian didasarkan pada prosedur dan kriteria yang jelas, tidak dipengaruhi subjektivitas penilai.

c. adil, berarti penilaian tidak menguntungkan atau merugikan peserta didik karena berkebutuhan khusus serta perbedaan latar belakang agama, suku, budaya, adat istiadat, status sosial ekonomi, dan gender.

d. terpadu, berarti penilaian oleh pendidik merupakan salah satu komponen yang tak terpisahkan dari kegiatan pembelajaran.

e. terbuka, berarti prosedur penilaian, kriteria penilaian, dan dasar pengambilan keputusan dapat diketahui oleh pihak yang berkepentingan.

f. menyeluruh dan berkesinambungan, berarti penilaian oleh pendidik mencakup semua aspek kompetensi dengan menggunakan berbagai teknik penilaian yang sesuai, untuk memantau perkembangan kemampuan peserta didik.

g. sistematis, berarti penilaian dilakukan secara berencana dan bertahap dengan mengikuti langkah-langkah baku.

h. beracuan kriteria, berarti penilaian didasarkan pada ukuran pencapaian kompetensi yang ditetapkan.

i. akuntabel, berarti penilaian dapat dipertanggungjawabkan, baik dari segi teknik, prosedur, maupun hasilnya.

2. Kendala dan Solusi dalam Pelaksanaan Stategi Kementerian Agama dalam meningkatkan mutu manajemen madrasah Aliyah

Dalam melakukan setrategi untuk meningkatkan mutu Madrasah Aliyah terjadi beberapa kendala yang harus dihadapi oleh Kemeterian Agama Kabupaten Seluma. Kendala yang terjadi dalam peningkatan mutu Madrasah Aliyah, diantaranya seperti:

1) Sumber Daya Manusia

a. Guru dan tenaga kependidikan masih banyak yang berijazah S1, Standar Pendidik dan Tenaga Kependidik merupakan standar nasional Pendidik harus memiliki kualifikasi akademik dan kompetensi sebagai agen pembelajaran, sehat jasmani dan rohani, serta memiliki kemampuan untuk mewujudkan tujuan pendidikan nasional.

b) Penguasaan IT rendah

Rendahnya kemampuan memanfaatkan IT pada era modernisasi ini menjadi sebab tertinggalnya informasi di beberapa pihak. Untuk meningkatkan mutu Madrasah Aliyah, kementrian agama harus bersama-sama dengan seluruh pihak terkait bahu-membahu meningkatkan informasi yang dapat mendukung peningkatan mutu Madrasah Aliyah di kabupaten Seluma. Kurangnya kemampuan dalam pemanfaatan IT untuk memperoleh informasi dan ajang komunikasi forum melambatkan proses peningkatan mutu Madrasah Aliyah di kabupaten seluma.

2) Sarana Prasarana kurang memadai

Salah satunya adalah standar sarana dan prasarana, beberapa Madrasah Aliyah masih mengalami kekurangan sarana prasarana seperti kekurangan ruang belajar, tempat berolahraga, tempat beribadah, dan perpustakaan. Selain itu minimnya sumber belajar yang dimiliki Madrasah Aliyah menjadi kendala tersendiri dalam proses pembelajaran di Madrasah Aliyah.

Beberapa kendala yang terjadi mengharuskan kementerian agama Kabupaten Seluma bekerja ekstra untuk dapat mengatasinya. Upaya-upaya untuk dapat Mengatasi Kendala dalam Peningkatan Mutu Madrasah Aliyah dilakukan melalui cara:

a) Memotivasi guru agar menempuh pendidikan yang lebih tinggi.

Salah satu bentuk dukungan yang diberikan kepada pendidik adalah dengan memberikan motivasi. Memberikan dorongan atau pemberian daya penggerak yang menciptakan kegairahan kerja seseorang agar mereka mau bekerja sama, bekerja efektif, dan terintegrasi dengan segala daya upayanya untuk mencapai kepuasan.

b) Mengikut sertakan guru dalam workshop dan pelatihan

Workshop dan pelatihan dilaksankan dengan dipandu oleh si pelatih dan praktik apa yang diajarkan. Workshop guru dimasksud disini adalah pelatihan bagi guru mdrasah Aliyah (MA) untuk dapat meningkatkan kompetensinya. 
Suhirman | Strategi Kementerian Agama Dalam Meningkatkan Mutu 124

c) Mengaktifkan kegiatan KKG

KKG sebagai wadah pengembangan profesionalisme guru, diharapkan dengan terlaksananya kegiatan-kegiatan kelompok kerja guru dapat lebih terarah dan dapat dijadikan wadah untuk pengembangan profesionalisme guru secara mandiri dan berkelanjutan.

d) Menggunakan media internet dan alat komunikasi dan social media e-mail, WA, SMS dan sejenisnya

Kini teknnologi informasi dan komunikasi (TIK) sudah menjadi bagian dari gaya hidup masyarakat Indonesia. Tidak an kalah pentingnya adalah guru dalam pemanfaatan TIK dalam proses pembelajaran dan kegiatan lain. Guru yang merupakan salah satu bagian terpenting dalam proses pembelajaran di Madrasah sebenarnya memerlukan berbagai piranti dalam mengoptimalkan pemanfaatkan TIK dan komunikasi untuk mendukung kemampuannya yang diperlukan khususnya dalam operasional perangkat TIK tersebut.

Mengingat guru banyak menghadapi tantangan berat dalam menjalankan tugas. Apabila diberikan suatu pernghargaan dan reward kepada guru, pasti bisa memotivasi kinerja para guru, agar semangat dan pantang mengeluh. Oleh karena itu, tidak ada ruginya apabila mencoba metode memberikan reward ini sebagai upaya motivasi kepada guru untuk peningkatan mutu Madrasah Aliyah.

\section{Kesimpulan}

Berdasarkan hasil penelitian dan pembahasan di atas dapat disimpulkan bahwa:

1. Strategi kementrian agama dalam peningkatan mutu manajemen Madrasah Aliyah di Kabupaten Seluma dengan cara meningkatkan mutu akademik dan non akademik dengan memenuhi 8 standar pendidikan nasional sesuai dengan PP No. 32 Tahun 2013 yang meliputi standar isi, standar proses, standar sarana dan prasarana, standar kompetensi kelulusan, standar kompetensi pengelolaan, standar kompetensi pembiayaan, standar kompetensi pendidik dan tenaga kependidikan serta standar kompetensi penilaian.

2. Kendala yang dialami oleh kementerian agama Kabupaten Seluma dalam meningkatkan mutu manajemen Madrasah Aliyah seperti guru dan tenaga pendidik yang belum memenuhi standar akademik, masih rendahnya kemampuan memanfaatkan IT, dan Sarana Prasarana kurang memadai.

3. Solusi mengatasi mengatasi kendala dalam peningkatan mutu manajemen Madrasah Aliyah yang dilakukan oleh kementerian agama Kabupaten Seluma adalah memotivasi guru agar meningkatkan kualifikasi pendidikan, mengikut sertakan guru dalam workshop dan pelatihan, mengaktifkan kegiatan $\mathrm{KKG}$, dan harus bisa menggunakan IT seperti internet, alat komunikasi dan social media lainnya.

\section{Daftar Pustaka}

Arief Furchan. Transformasi pendidikan Islam di Indonesia, Anatomi keberadaan madrasah dan PTAI. Yogyakarta. gama Media.2002.

Abudin Nata, Manajemen Pendidikan: Mengatasi Kelemahan Pendidikan Islam di Indonesia, Edisi Kedua, cet. Ke-3 (Jakarta: Kencana Predia Media Group, 2008)

Abdul Manab. Manajemen Kurikulum Pembeajaran di Madrasah

Abuddin Nata, Sejarah Pendidikan Islam pada Periode Klasik dan Pertengahan,, (Jakarta: PT. Raja Grafindo Persada, 2004)

Abdul Chafidz, Sekolah Unggul Konsepsi dan Problematikanya, (MPA No. 142, Juli 1998)

A.M. Sardiman. Interaksi dan Motivasi Belajar Mengajar. (Jakarta: Raja Grafindo Persada, 2001)

Adiyanto. Strategi Kementerian Agama Kabupaten Cilacap Dalam Peningkatan Mutu Madrasah Ibtidaiyah Di Kabupaten Cilacap. IAIN.Purwokwerto. 2016.

Dasman Yanuri. Minat Masyarakat Menyekolahkan Anaknya Ke Sekolah Menengah Pertama (SMP) dan Madrasah Tsanawiyah (MTs) di Kecamatan Semidang Gumay Kabupaten Kaur. IAIN Bengkulu Tahun 2016

Djamarah, Syaiful Bahri. Guru dan Anak Didik dalam Interaksi Edukatif. (Jakarta: Rineka Cipta, 2000)

A. Mulyasa. Menjadi Guru Profesional Menciptakan Pembelajaran Kreatif dan Menyenangkan. (Bandung: Remaja Rosdakarya Offset. 2006)

Edward Sallis, Total Quality Manajemen. In Education. Manajemen Mutu Pendidikan. Yogyakarta.IRCisod. 2008

F William R. Manajemen Strategis dan Kebijakan Perusahaan.

H.S, Salim, Hukum Kontrak Teori dan Teknik Penyusunan Kontrak,(Jakarta: Sinar Grafika, 2004)

https://sumsel.kemenag.go.id/artikel/39212/tugas-dan-fungsi-struktur-kemenag-sumsel

http://pendis.kemenag.go.id/index.php?a=artikel \&id2=sejarahpendis\#.WFiTA9J97IU 
Suhirman | Strategi Kementerian Agama Dalam Meningkatkan Mutu 125

http://deuniv.blogspot.co.id/2015/03/pengenalansnp-spm-dan-spmp-dalam.html

Habib Husnial Pardi. Sejarah Sosial Pendidikan Islam ,Kencana Jakarta,2005.

Hamzah B. Uno. Teori motivasi dan pengukuran analisis di bidang pendidikan, (Jakarta: bumi aksara, 2008)

Jerome As Arcaro, Pendidikan Berbasis mutu prinsip-prinsip perumusan dan tata langkah penerapan.Yogyakarta. Pustaka Pelajar. 2007.

Keputusan Menteri Negara Pendayagunaan Aparatur Negara Nomor 118/1996

Molleong J. Lexy, Penelitian Kualittaif, (Bandung, Remajarosdakarya, 1995)

Nana Syaudih, Pengendalian mutu pendidikan sekolah menengah. Bandung Refika Aditiya. 2003.

Rahardjo, Madrasah sebagai The Centre of Excellence. www.pendis.go.id/madrasah diakses tanggal 2016.

Sandra Oliver, Strategi Public Relations, PT. Gelora Aksara Pramata, London: 2006.

Syaiful Sagala, Manajemen Strategik dalam Peningkatan Mutu Pendidikan, (Bandung: Alfabeta, 2006)

Suwito. Sejarah Sosial Pendidikan Islam. Jakarta, Kencana. 2005.

Sandra Oliver, Strategi Public Relations, PT. Gelora Aksara Pramata, London: 2006.

Syaiful Sagala, Manajemen Strategik dalam Peningkatan Mutu Pendidikan, (Bandung: Alfabeta, 2006)
Sutrisno Hadi, Metode Research, (Yogyakarta, Andi, 2001)

Sugiono, Metode Penelitian Kuantitatif dan kualitatif. Jakarta Pustaka Pelajar. 2011.

Sagala, syaiful. konsep dan makna pembelajaran. (Bandung: alfabeta, 2011)

Tim Dosen Administrasi Pendidikan Universitas Pendidikan Indonesia. Manajemen Pendidikan (Bandung : Alfabeta, 2011)

Undang-undang dan Peraturan Pemerintah tentang pendidikan. Jakarta Dirjen Pendis Depag RI. 2006

Putikha Rahmaini. Manajerial kepala madrasah dalam meningkatkan mutu pendidikan di Madrasah Aliyah Negeri 1 (model) Lubuklinggau. IAIN Bengkulu Tahun 2016

Profil Kemenag RI.Pendis Kemenag. Jakarta. LITBANG.Tahun 2013.

Profil Kantor Kementerian Agama Kabupaten Seluma Tahun 2016.

PeraturanPemerintah Nomor 32 Tahun 2013 tentang Standar. Nasional Pasal 2 Ayat 2b

Pedoman pembinaan pengawas madrasah dan pengawas pendidikan agama islam pada skeolah. 2014. Kementrian agama RI: Direktorat jenderal pendidikan islam.

PP nomor 17 tahun 2010 (PP nomor 66 tahun 2010) tentang pengelolaan dan penyelenggaraan pendidikan

Zulkarnain, Transformasi nilai-nilai pendidikan Islam. Jakarta. Pustaka Pelajar. 2008. 
Suhirman | Strategi Kementerian Agama Dalam Meningkatkan Mutu 126 